\title{
EFEKTIVITAS KONSELING KELOMPOK REALITA UNTUK MENURUNKAN KECEMASAN PADA KLIEN PEMASYARAKATAN
}

\author{
Bayu Febrianto ${ }^{1}$, Tri Kurniati Ambarini ${ }^{2}$ \\ ${ }^{1,2}$ Fakultas Psikologi, Universitas Airlangga Surabaya \\ ${ }^{1}$ bayufebriantonew@gmail.com, ${ }^{2}$ tri.ambarini@psikologi.unair.ac.id
}

\begin{abstract}
Abstrak. Kecemasan merupakan masalah yang umum yang kerap dirasakan oleh manusia. Klien pemasyarakatan yang merupakan narapidana yang telah kembali ke masyarakat juga mengalami kecemasan, yang berpotensi menimbulkan masalah. Kecemasan pada klien pemasyarakatan akan mengganggu tujuan dari program reintegrasi yang diberikan, sehingga perlu diberikan tindakan yang sesuai untuk menurunkan tingkan kecemasan tersebut. Konseling kelompok realita merupakan metode yang dapat dilakukan untuk menurunkan tingkat kecemasan pada klien pemasyarakatan. Penelitian ini bertujuan untuk mengukur efektivitas dari konseling kelompok realita untuk menurunkan kecemasan pada klien pemasyarakatan di Balai Pemasyarakatan Kelas II Mataram. Desain penelitian adalah quasi experimental - nonequvalent control group pre-test/post-test, menggunakan Taylor Manifest Anxiety Scale (TMAS). Hasil analisis data menunjukkan adanya perbedaan yang signifikan antara kelompok eksperimen dan kelompok kontrol setelah diberikan intervensi. Artinya adalah konseling kelompok realita efektif untuk menurunkan kecemasan pada klien pemasyarakatan di Balai Pemasyarakatan Kelas II Mataram.
\end{abstract}

Kata kunci: kecemasan, konseling kelompok realita

Abstract. Anxiety is a common problem that people felt. Correctional clients who have returned to the community also experience anxiety, which could cause problems. Anxiety in correctional clients will interfere with the purpose of the re-integration program provided, so that appropriate intervention need to be given to reduce the anxiety. Reality group counseling is a method that can be done to reduce anxiety levels in correctional clients. This study aims to measure the effectiveness of group counseling reality to reduce anxiety in correctional clients at Balai Pemasyarakatan Kelas II Mataram. The study design was quasi experimental - nonequvalent control group pretest/post-test, using the Taylor Manifest Anxiety Scale (TMAS). The results of data analysis showed a significant difference between the experimental group and the control group after being given an intervention. This means that group reality counseling is effective for reducing anxiety in correctional clients at Balai Pemasyarakatan Kelas II Mataram.

Keywords: anxiety, reality group counseling 
Individu yang menjalani hukuman pidana di dalam penjara (Lembaga Pemasyarakatan) merupakan seorang narapidana atau disebut warga binaan pemasyarakatan. Seseorang yang menyandang status narapidana akan terenggut kebebasannya dan meninggalkan kehidupan yang telah dijalani sebelumnya. Kehidupan mereka di dalam sebuah penjara pun dibatasi oleh aturan-aturan yang ada. Hal tersebut diatur dalam UU No. 12 Tahun 1995 tentang Pemasyarakatan. Segala bentuk pola kehidupan tersebut adalah bentuk tanggung jawab atau konsekuensi dari perbuatan yang telah diperbuat. Undang-undang Pemasyarakatan Republik Indonesia tidak hanya mengatur tentang kewajiban dari warga binaan pemasyarakatan saja, melainkan juga memperhatikan hak-hak yang layak mereka terima.

Undang-Undang Nomor 12 Tahun 1995 menjelaskan bahwa Warga Binaan Pemasyarakatan telah dijamin hak-haknya, salah satunya berhak mendapatkan mengurangan masa pidana atau Remisi, Asimilasi, Cuti Mengunjungi Keluarga serta Pembebasan Bersyarat dan Cuti Menjelang Bebas. Narapidana yang telah berkelakuan baik dan tidak pernah melakukan pelanggaran memiliki hak untuk mendapatkan remisi ataupun program re-integrasi sosial (Permenkumham No. 3 Tahun 2018). Program remisi dan juga re-integrasi sosial merupakan hak khusus yang diberikan kepada narapidana yang berkelakuan baik dan tidak pernah terdaftar dalam Register F (daftar bermasalah).

Remisi merupakan pengurangan menjalani masa pidana yang diberikan kepada narapidana yang memenuhi syarat yang ditentukan oleh ketentuan peraturan perundangundangan. Program re-integrasi sosial berupa asimilasi, cuti mengunjungi keluarga $(\mathrm{CMK})$, cuti bersyarat $(\mathrm{CB})$, cuti menjelang bebas $(\mathrm{CMB})$, dan pembebasan bersyarat (PB) merupakan kegiatan membaurkan narapidana kembali kepada masyarakat dengan tujuan mengintegrasikan narapidana ke dalam kehidupan masyarakat setelah memenuhi ketentuan yang berlaku. Khusus untuk program re-integrasi sosial yaitu CB, CMB, dan $\mathrm{PB}$, narapidana tidak lagi menjalani masa pidananya di dalam Lapas, melainkan akan bebas terlebih dahulu dan kembali ke masyarakat dengan syarat-syarat tertentu. Tanggung jawab pengawasan program tersebut, tidak lagi menjadi tanggung jawab Lembaga Pemasyarakatan, melainkan berpindah ke Balai Pemasyarakatan (Permenkumham No. 3 Tahun 2018).

Balai Pemasyarakatan yang selanjutnya disebut Bapas adalah pranata untuk melaksanakan bimbingan klien pemasyarakatan (UU RI No. 12 Tahun 1995). Balai Pemasyarakatan mempunyai tugas dan fungsi menyelenggarakan sebagian tugas pokok Direktorat Jendral Pemasyarakatan dalam menyelenggarakan pembimbingan klien pemasyarakatan di daerah. Balai Pemasyarakatan memberikan perspektif lain yang lebih objektif sebagai dasar pembuatan keputusan bagi aparat penegak hukum lainnya dalam memberikan keputusan hukum yang tepat dan adil. Pada tahap post adjudikasi, Balai Pemasyarakatan ikut di dalam melakukan proses pembinaan dalam rangka admisi orientasi, asimilasi dan reintegrasi serta perlindungan anak. Bentuk bimbingan yang diberikan bermacam-macam, mulai dari pemberian pembinaan tentang agama, keterampilan, sampai pada pembinaan kepribadian. Bimbingan ini diberikan dengan tujuan agar Klien Pemasyarakatan dapat hidup dengan baik di dalam masyarakat dan tidak mengulangi kembali tindak kejahatan. 
Balai Pemasyarakatan Kelas II Mataram merupakan salah satu unit pelaksana teknis (UPT) yang menjalankan empat tugas dan fungsi dari Balai Pemasyarakatan, yaitu pembuatan Penelitian Kemasyarakatan (Litmas), pembimbingan, pengawasan, dan pendampingan. Balai Pemasyarakatan Mataram merupakan salah satu UPT yang dibawahi oleh Kantor Wilayah (Kanwil) Kementerian Hukum dan HAM Nusa Tenggara Barat. Balai Pemasyarakatan Mataram dalam melaksanakan tugasnya memiliki jangkauan tugas di seluruh Pulau Lombok, dengan jumlah klien kurang lebih sejumlah 744 klien laki-laki dan 29 klien perempuan (Sistem Database Pemasyarakatan Bapas Mataram).

Klien Pemasyarakatan atau yang kemudian disebut klien adalah seseorang yang berada dalam bimbingan Bapas (UU RI No. 12 Tahun 1995). Menurut Peraturan Pemerintah Nomor 31 Tahun 1999, dijelaskan bahwa klien memiliki beberapa jenis salah satunya adalah narapidana yang telah mendapatkan program reintegrasi sosial sehingga telah bebas secara bersyarat dan tanggung jawab pengawasannya berpindah dari Lapas kepada Bapas. Narapidana yang yang menjadi klien, sudah tidak lagi terenggut kemerdekaannya secara utuh, karena telah bisa kembali ke masyarakat dan tinggal bersama keluarganya, akan tetapi masih memiliki kewajiban dan tanggung jawab yang diatur oleh Bapas.

Narapidana yang kembali ke tengah-tengah masyarakat tak lepas dari permasalahan pribadi masing-masing. Salah satu permaslahan yang dihadapi oleh klien pemasyarakatan adalah kecemasan (Western dkk, 2014; Schnittker, Massoglia, dan Uggen, 2012; Shinkfield dan Graffam, 2010; ) yang bahkan telah terjadi sejak masih berstatus sebagai narapidana (Patandean, 2017) karena para mantan narapidana merasa takut akan banyak hal; mereka merasa tidak memiliki apapun dan tidak layak untuk kembali ke masyarakat; mereka merasa banyak hal yang tidak mereka ketahui tentang dunia luar karena mereka terbiasa hidup di dalam penjara (Chikadzi, 2017).

Kecemasan yang terjadi pada klien pemasyarakatan di Balai Pemasyarakatan Kelas II Mataram adalah klien yang akan menerima program reintegrasi sosial merasa khawatir mengenai penerimaan keluarga maupun masyarakat di lingkungan tempat tinggal mereka akan kehadiran mereka kembali. Mereka merasa perbuatan mereka telah mencoreng nama baik lingkungan sehingga tidak layak lagi untuk diterima masyarakat. Klien yang tidak dijemput oleh keluarganya ketika bebas merasa bahwa mereka sudah tidak dianggap lagi oleh keluarganya. Mereka merasa bahwa keluarga tidak lagi mengharapkan kehadiran mereka, sehingga tidak ada yang datang untuk menjemput. Klien juga khawatir tentang pekerjaan. Beberapa klien yang belum lama kembali ke masyarakat mengatakan bahwa belum mendapatkan pekerjaan. Mereka khawatir apabila tidak ada yang mau memperkerjakan mereka karena berstatus sebagai mantan narapidana. Mereka takut apabila tidak dapat memenuhi kebutuhan keluarga, maka pasangan dan anak-anak akan meninggalkan mereka.

Kecemasan yang terjadi pada para mantan narapidana dapat dikarenakan oleh beberapa hal. Moran (2015) menjelaskan bahwa alasan mantan narapidana merasa cemas ketika menghadapi dunia luar adalah ketika mereka berada di dalam penjara, mereka tidak cukup mendapatkan informasi mengenai apa yang terjadi di luar. Hal tersebut menyebabkan mereka bingung dan takut menjadi tidak bisa mengikuti perkembangan yang ada di luar penjara. Para mantan narapidana merasa kesusahan dalam beradaptasi 
dengan kegiatan sehari-hari. Selain itu, Hanun (2013) menjelaskan bahwa mantan narapidana memiliki hambatan dalam proses penyesuaian diri ketika telah kembali ke masyarakat yaitu perasaan malu dengan status sebagai mantan narapidana, rasa cemas dan takut apabila kelak akan kembali terlibat masalah atau tindak pidana, dan juga belum bisa menerima status sebagai mantan narapidana sehingga harus menutupi jati dirinya sendiri. Masalah tebesar dari mantan narapidana adalah sikap mereka terhadap dirinya yang menganggap dirinya sendiri tidak berguna sehingga menjadi putus asa di tengah masyarakat (Gorgulu \& Erden, 2015).

Kecemasan merupakan suatu masalah yang umum terjadi pada mantan narapidana. Kecemasan merupakan respon normal yang dimunculkan oleh diri kita yang dapat membantu diri kita untuk mempersiapkan sebuah tindakan dan juga membantu kita membuat rencana untuk menghadapi berbagai situasi. Kondisi ini sangat berhubungan dengan ketakutan, khawatir, dan juga tegang ketika menghadapi berbagai situasi. Kecemasan menjadi masalah ketika telah menyerap energi kita dan menghalangi kita dalam melakukan kegiatan sehari-hari (Dixon, 2012). Kecemasan merupakan sebuah kondisi yang terkait dengan rasa takut, dimana setiap orang memiliki respon yang berbeda-beda. Respon tersebut dipengaruhi oleh proses belajar ketika menghadapi stimulus tertentu. Menjadi hal yang wajar ketika seseorang merasa cemas ketika menghadapi situasi yang ditakuti, sehingga memunculkan respon yang tepat. Hal tersebut menjadi abnormal ketika proporsi respon yang ditimbulkan tidak sesuai dengan stimulus yang muncul, yang kerap membentuk fobia. Rasa takut adalah normal, sedangkan fobia adalah abnormal. Keduanya berada pada kontinum yang sama, yang membedakannya adalah derajatnya, bukan jenisnya. (Seligman, Walker, \& Rosenhan, 2001). Kecemasan bisa menjadi abnormal apabila direspon melebihi proporsi ancaman yang datang, atau muncul tanpa adanya stimulus yang nyata, yang dalam tingkat ekstrem akan mengganggu fungsi hidup sehari-hari (Nevid, Rathus, \& Greene, 2003).

Dukungan sosial maupun pendampingan memiliki andil yang cukup besar dalam usaha menurunkan tingkat kecemasan (Amelia, 2010). Gorgulu dan Erden (2015) menyatakan bahwa dukungan dari lingkungan sekitar terutama keluarga merupakan kebutuhan mendesak yang diperlukan oleh mantan narapidana. Melakukan penanganan terhadap masalah maupun gangguan psikolgis merupakan salah satu strategi untuk melaksanakan reintegrasi bagi mantan narapidana dan merupakan mekanisme untuk menormalkan penyimpangan (Schnittker, Massoglia, dan Uggen, 2012).

Bentuk dukungan sosial sebagai salah satu pilihan dalam menanggulangi masalah psikologis salah satunya adalah konseling kelompok karena konseling kelompok memberikan solusi yang nyata berupa masukan dari orang lain sesama anggota kelompok yang memiliki kondisi yang serupa (Dadashazar, 2017). Konseling kelompok merupakan bentuk khusus dari layanan konseling, yaitu proses konseling antara konselor profesional dengan beberapa konseli sekaligus yang tergabung dalam sebuah kelompok kecil pada waktu yang sama (Astuti, 2012). Selanjutnya, Corey \& Corey (2009) menjelaskan bahwa seorang ahli dalam konseling kelompok mencoba membantu peserta untuk menyelesaikan kembali permasalahan hidup yang umum dan sulit seperti: permasalahan pribadi, sosial, belajar/akademik, dan karir. Konseling kelompok lebih memberikan perhatian secara umum pada permasalahan-permasalahan jangka pendek dan tidak terlalu memberikan perhatian pada treatmen gangguan perilaku dan psikologis. Konseling 
kelompok memfokuskan diri pada proses interpersonal dan strategi penyelesaian masalah yang berkaitan dengan pemikiran, perasaan, dan perilaku yang disadari. Metode yang digunakan adalah dukungan dan umpan balik interaktif dalam sebuah kerangka berpikir here and now (di sini dan saat ini).

Pemberian konseling kelompok bagi klien pemasyarakatan akan memberikan kesempatan bagi klien pemasyarakatan untuk saling berbagi tentang masalah yang dihadapinya. Masing-masing klien bisa mendapatkan solusi nyata dari klien lainnya yang mungkin memiliki masalah yang sama dengan dirinya dan telah memecahkan masalah tersebut. Klien dalam konseling kelompok bisa mendapatkan metode pemecahan masalah yang nyata dari klien lainnya. Konseling kelompok memberikan kemungkinan untuk bertukar pengalaman antara antara anggota kelompok karena masing-masing mereka memiliki karakteristik yang serupa. Masukan dan pemikiran dari beberapa orang tentu akan lebih baik daripada solusi yang berasal hanya dari satu orang saja.

Pendekatan dalam pelaksanaan konseling kelompok yang akan diberikan kepada klien pemasyarakatan adalah pendekatan realita. Terapi realita dikembangkan sebagai reaksi yang menolak konsep-konsep terapi konvensional. Terapi realita merupakan proses intervensi yang menekankan pada kondisi saat ini, fokus pada kekuatan pribadi, dan mendorong individu untuk mengembangkan tingkah laku yang lebih realistis sebagai bentuk dari tanggung jawab terhadap pilihan yang dilakukan agar dapat mencapai kesuksesan (Corey, 2009). Konseling realita merupakan sebuah proses komunikasi antara konselor dan klien mengenai pilihan-pilihan yang akan diambil dalam hidupnya. Tidak ada yang lebih berperan dalam hidup seseorang melebihi pilihan hidupnya sendiri.

Pada proses konseling, konselor membantu klien untuk menyadari bahwa setiap pilihan yang ia ambil akan memiliki konsekuensi yang akan ia tanggung. Klien diajak untuk menyusun rencana-rencana yang akan digunakan untuk mencapai perubahan ke arah yang lebih baik dengan proses konseling realita (Glasser, 2004). Pelaksanaan konseling kelompok realita yang akan diberikan menggunakan langkah WDEP, yaitu wants, direction and doing, evaluation, dan planning. Langkah-langkah dalam pelaksanaan konseling kelompok realita tersebut akan memberikan kesempatan bagi klien pemasyarakatan untuk memahami kondisinya dan menyusun rencana yang realistis agar dapat menjadi lebih baik.

Konseling berkelompok dilaporkan dapat menurunkan tingkat kecemasan secara signifikan pada narapidana (Gharavi, Kashani, Lotfi, \& Borhani, 2015). Pemberian konseling kelompok dengan pendekatan realita diketahui secara signifikan dapat menurunkan tingkat stress, kecemasan, dan depresi (Farmani, Taghavi, Fatemi, \& Safavi, 2015). Yuliana (2015) menjelaskan bahwa konseling kelompok dapat mengatasi kecemasan karena anggota kelompok mendapatkan kesempatan untuk saling belajar dan mengajarkan kepada satu sama lain tentang bagaimana mengatasi masalah yang dihadapi.

Konseling secara berkelompok dengan pendekatan realita merupakan salah satu program yang tepat sebagai salah satu program pembimbingan bagi klien pemasyarakatan. Kegiatan pembimbingan merupakan kegiatan yang wajib dilaksanakan oleh Balai Pemasyarakatan (Bapas) yang berbentuk bimbingan kemandirian dan juga bimbingan kepribadian (Peraturan Pemerintah Nomor 31 Tahun 1999). Balai Pemasyarakatan Kelas 
II Mataram sudah memiliki kegiatan pembimbingan yang dilaksanakan setiap bulan sekali. Kegiatan pembimbingan tersebut dilakukan secara bergantian dalam bentuk bimbingan kemandirian dan bimbingan kepribadian, yang diberikan secara berkelompok. Bentuk bimbingan yang telah diberikan selama ini di Balai Pemasyarakatan Mataram belum pernah dilakukan dalam bentuk konseling kelompok, khususnya dengan pendekatan realita untuk menurunkan kecemasan pada klien pemasyarakatan. Berdasarkan hal tersebut konseling kelompok dengan pendekatan ralita dirasa efektif untuk menurunkan kecemasan pada klien pemasyarakatan di Balai Pemasyarakatan Kelas II Mataram.

\section{METODE PENELITIAN}

Penelitian ini menggunakan desain quasi experimental - nonequvalent control group pretest/post-test design. Metode ini dapat dijelaskan dengan gambar sebagai berikut:

$$
\begin{aligned}
& \text { Kelompok eksperimen } \mathrm{O}_{1} \longrightarrow \mathrm{X} \longrightarrow \mathrm{O}_{2} \\
& \text { Kelompok kontrol } \mathrm{O}_{3} \longrightarrow \mathrm{O}_{4}
\end{aligned}
$$

Keterangan:

O1 : kondisi kelompok eksperimen pre-test

O2 : kondisi kelompok eksperimen post-test

$\mathrm{X}$ : perlakuan

O3 : kondisi kelompok kontrol pre-test

O4 : kondisi kelompok kontrol post-test

Penelitian ini terdiri dari dua variabel penelitian, yaitu variabel bebas dan variabel terikat. Variabel bebas dalam penelitian ini adalah konseling kelompok realita, sedangkan variabel tergantung dalam penelitian ini adalah kecemasan. Konseling kelopok realita adalah proses konseling dengan beberapa konseli sekaligus yang tergabung dalam sebuah kelompok kecil yang berfokus pada kekuatan pribadi, dan mendorong individu untuk mengembangkan tingkah laku yang lebih realistis sebagai bentuk dari tanggung jawab terhadap pilihan yang dilakukan agar dapat mencapai kesuksesan. Konseling kelompok realita pada penelitian ini akan menggunakan langkah WDEP, yaitu wants, direction and doing, evaluation, dan planning. Berdasarkan langkah tersebut konseling kelompok akan dibagi menjadi 4 (empat) pertemuan sesuai dengan tiap-tiap langkah.

Subjek penelitian diambil dengan cara purposive sampling. Subjek penelitian yang digunakan dalam penelitian ini adalah klien pemasyarakatan yang menjalani proses pembimbingan di Balai Pemasyarakatan Kelas II Mataram dengan kriteria sebagai berikut: (1) Klien Sub Seksie Bimbingan Klien Dewasa; (2) Telah bebas $\leq 1$ bulan; (3) Bisa membaca dan menulis; (4) Bersedia mengikuti kegiatan intervensi yang telah disusun, (5) Mendapatkan tingkat kecemasan sedang - tinggi pada skala TMAS.

Peneliti melakukan pemilihan subjek penelitian pada saat kegiatan wajib lapor yang dilaksanakan setiap bulan di Balai Pemasyarakatan Kelas II Mataram. Peneliti 
mengajukan pertanyaan kepada klien yang hadir pada kegiatan tersebut. Berdasarkan kriteria subjek penelitian yang ada, didapatkan 12 orang klien pemasyarakatan yang telah bebas bersyarat $\leq 1$ bulan, dan hanya 9 orang yang mendapatkan skor kecemasan sedangtinggi sesuai Skala TMAS. Peneliti membagi subjek yang ada ke dalam kelompok eksperimen dan kelompok kontrol. Guna mendapatkan proporsi subjek yang seimbang, subjek yang digunakan hanya 8 orang. Kelompok eksperimen mendapatkan intervensi berupa konseling kelompok realita sedangkan kelompok kontrol tidak mendapatkan intervensi serupa tetapi diberikan psikoedukasi mengenai kecemasan.

Alat ukur dalam penelitian ini menggunakan Taylor Manifest Anxiety Scale (TMAS) yang berisi 50 aitem. Aitem-aitem yang ada dibagi menjadi dua kategori yaitu aitem favorable dan unfavorable. Aitem-aitem ini berupa pernyataan yang memiliki dua pilihan jawaban yaitu "YA" dan "TIDAK". Skala inilah yang digunakan untuk menentukan karakteristik awal responden yang akan digunakan sebagai subjek penelitian dan juga sebagai alat ukur pada pretest dan posttest.

Skor yang diperoleh dari skala penelitian digunakan untuk membandingkan apakah skor sesudah pemberian intervensi lebih rendah atau lebih tinggi daripada sebelum intervensi sehingga dapat diketahui efektivitas dari intervensi yang diberikan. Hasil intervensi dapat dilihat dengan cara melakukan uji beda terhadap kelompok eksperimen dan kelompok kontrol. Adapun teknik analisa data yang digunakan dalam penelitian ini menggunakan prosedur non parametrik Mann Whitney Test dengan menggunakan bantuan program komputasi SPSS for Windows Release 20.0.

Efektivitas dari intervensi yang diberikan terhadap perubahan nilai variabel terikat akan dihitung melalui effect size. Effect Size ini merupakan suatu perhitungan yang bertujuan untuk mengetahui besarnya efektivitas suatu perlakuan terhadap variabel terikat (Field, 2009).

\section{HASIL PENELITIAN}

Analisis deskriptif dilakukan untuk dapat mengetahui perubahan skor kecemasan pada masing-masing kelompok; pretest kelompok kontrol, posttest kelompok kontrol, pretest kelompok eksperimen, dan posttest kelompok eksperimen. Berdasarkan nilai mean dan standar deviasi masing-masing kelompok, dapat diketahui perubahan tingkat kecemasan pada subjek penelitian. Adapun data deskriptif dari masing-masing kelompok dijabarkan sebagai berikut:

Tabel 1. Data Deskriptif Tiap Kelompok

\begin{tabular}{lccccc}
\hline & N & Minimum & Maximum & Mean & Std. Deviation \\
\hline PreKontrol & 4 & 26 & 31 & 27.50 & 2.380 \\
PostKontrol & 4 & 26 & 30 & 27.50 & 1.915 \\
PreEks & 4 & 25 & 37 & 29.25 & 5.315 \\
PostEks & 4 & 10 & 17 & 12.50 & 3.109 \\
Valid N (listwise) & 4 & & & &
\end{tabular}

Berdasarkan nilai mean dan standar deviasi pada tabel 1 dapat diketahui kategorisasi tingkat kecemasan masing-masing kelompok dalam penelitian ini. Jika merujuk pada 
nilai mean pada skor pretest dan posttest kelompok kontrol, tidak ditemukan penurunan pada rata-rata skor kecemasan, sedangkan jika merujuk pada nilai mean pada skor pretest dan posttest kelompok eksperimen, ditemukan adanya penurunan pada rata-rata skor kecemasan.

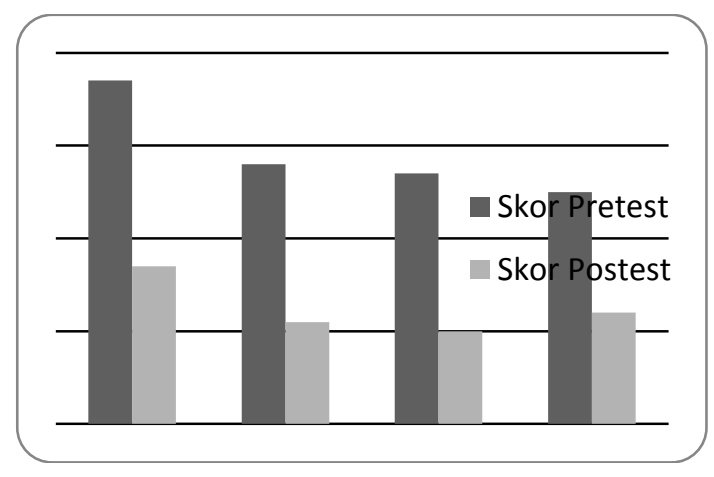

\section{Gambar 2. Grafik Rata-Rata Skor Kecemasan Pada Kelompok Eksperimen}

Berdasarkan data yang disajikan dalam gambar 2 diketahui bahwa terjadi penurunan tingkat kecemasan pada kelompok eksperimen yang diberikan intervensi berupa konseling kelompok realita. Maknanya adalah konseling kelompok memberikan pengaruh berupa menurunnya tingkat kecemasan pada klien pemasyarakatan.

Uji beda antara kelompok eksperimen dan kelompok kontrol pada penelitian ini menggunakan teknik non parametric test - 2 independent samples. Hasil dari analisis uji beda skor kecemasan pada kelompok eksperimen dan kelompok kontrol menggunakan program SPSS 20 for windows adalah sebagai berikut:

Tabel 2. Hasil Uji Beda Kelompok Kontrol dan Kelompok Eksperimen

\begin{tabular}{lc}
\hline & Nilai \\
\hline Mann-Whitney U & .000 \\
Wilcoxon W & 10.000 \\
Z & -2.323 \\
Asymp. Sig. (2-tailed) & .020 \\
Exact Sig. [2*(1-tailed Sig.)] & $.029^{\mathrm{b}}$ \\
\hline
\end{tabular}

Berdasarkan tabel 2 dapat diketahui bahwa nilai signifikansi perbedaan pada skor kecemasan kelompok eksperimen dan kelompok kontrol sebesar $0,020<0,05$. Maknanya adalah terdapat perbedaan yang signifikan antara skor kecemasan pada kelompok eksperimen dengan kelompok kontrol setelah adanya pemberian perlakuan. Berdasarkan hasil tersebut dapat diketahui bahwa subjek yang mendapatkan perlakuan berupa konseling kelompok realita memiliki tingkat kecemasan yang berbeda dari subjek yang tidak mendapatkan perlakuan berupa konseling kelompok realita.

Uji efektivitas dilakukan guna mengetahui efektivitas konseling kelompok realita untuk menurunkan kecemasan. Perhitungan nilai ES (effect size) pada kelompok eksperimen pada penelitian ini dilakukan dengan perhitungan secara manual. Adapun hasil perhitungan effect size adalah sebagai berikut: 
Tabel 3. Efektivitas Konseling Kelompok Realita

\begin{tabular}{cccccc}
\hline Mean Pretest & SD Pretest & $\begin{array}{c}\text { Mean } \\
\text { Posttest }\end{array}$ & $\begin{array}{c}\text { SD } \\
\text { Posttest }\end{array}$ & $\begin{array}{c}\text { Nilai } \\
\text { ES }\end{array}$ & Kategori \\
\hline 29,25 & 5,315 & 12,50 & 3,109 & 2,91 & $\begin{array}{c}\text { Efektivitas } \\
\text { Besar }\end{array}$ \\
\hline
\end{tabular}

Berdasarkan tabel 3 dapat diketahui bahwa nilai efektivitas konseling kelompok realita untuk menurunkan kecemasan berada pada rentang $\mathrm{X} \geq 0,8$ dengan nilai effect size 2,91. Hal tersebut membuktikan bahwa konseling kelompok realita memiliki efektivitas yang besar untuk menurunkan kecemasan pada kelompok eksperimen.

\section{DISKUSI}

Kecemasan yang menjadi fokus dalam penelitian ini adalah kecemasan yang dirasakan oleh klien pemasyarakatan atau mantan narapidana yang baru saja bebas secara bersyarat dari penjara. Konseling kelompok realita dipilih sebagai bentuk intervensi yang diberikan kepada klien pemasyarakatan yang mengalami kecemasan dengan harapan mereka bisa memahami kecemasan yang mereka alami dan lebih dari itu mereka bisa membuat rencana yang realistis bagi hidup mereka saat berada kembali di lingkungan masyarakat. Berdasarkan latar belakang tersebut, muncul pertanyaan mengenai efektivitas pemberian konseling kelompok realita untuk menurunkan kecemasan pada klien pemasyarakatan di Balai Pemasyarakatan Kelas II Mataram yang kemudian menjadi rumusan masalah dalam penelitian ini.

Analisis uji beda yang dilakukan untuk melihat perbedaan hasil posttest pada kelompok eksperimen dengan hasil posttest pada kelompok kontrol. Hasil yang diperoleh menunjukkan nilai signifikansi perbedaan sebesar $0,020<0,05$. Berdasarkan nilai tersebut dapat diketahui bahwa terdapat perbedaan yang signifikan antara kondisi kecemasan pada kelompok ekpserimen dengan kondisi kecemasan pada kelompok kontrol setelah pemberian intervensi berupa konseling kelompok realita.

Perbedaan kondisi kecemasan pada kelompok eksperimen dan kelompok kontrol dapat dilihat dari data deskriptif rata-rata skor kecemasan pada kelompok eksperimen dan kelompok kontrol. Diketahui bahwa terjadi penurunan nilai rata-rata skor kecemasan sebelum dan sesudah pemberian perlakuan berupa konseling kelompok realita pada kelompok eksperimen.

Kedua hasil di atas diberkuat dengan hasil perhitungan effect size yang memperoleh nilai EF sebesar 2,91. Nilai tersebut berada pada rentang $X \geq 0,8$ yang berarti berada pada ketegori efektivitas besar. Hasil perhitungan tersebut menunjukkan bahwa konseling realita memiliki efektivitas yang besar untuk menurunkan kecemasan pada klien pemasyarakatan di Balai Pemasyarakatan Kelas II Mataram. hasil tersebut sejalan dengan penelitian yang dilakukan Farmani dkk (2015) dengan hasil yang menyatakan bahwa terapi kelompok realita memeiliki efektivitas yang signifikan untuk menurunkan kecemasan pada pasien dengan multiple sclerosis (MS).

Pemberian konseling kelompok merupakan salah satu pilihan yang tepat untuk menurunkan kecemasan. Klien pemasyarakatan yang merupakan mantan narapidana 
menghadapi masalah ketika kembali ke masyarakat berupa susah memulihkan hubungan dengan keluarga dan masyarakat, menjadi pengangguran, perasaan inferior; kesusahan dalam menghadapi perubahan lingkungan (Chikadzi, 2017). Konseling kelompok membantu peserta untuk menyelesaikan kembali permasalahan hidup yang umum dan sulit seperti permasalahan pribadi, sosial, belajar/akademik, dan karir (Corey \& Corey, 2006). Hal tersebut sejalan dengan penelitian Brennan (2013) yang menyatakan bahwa partisipasi dalam grup memberikan keuntungan berupa tukar informasi antar anggota kelompok, belajar dari hubungan antar anggota kelompok, dan merasakan kesamaan dengan anggota kelompok lainnya.

Pada penelitian ini peneliti mencoba membantu klien pemasyarakatan untuk bangkit dan merencanakan kehidupan mereka agar bisa menjadi lebih baik dari sebelumnya. Hal tersebut sesuai dengan sifat dari konseling kelompok yaitu membantu individu-individu dengan cara mendorong pencapaian tujuan perkembangan dan memfokuskan pada kebutuhan dan kegiatan belajarnya. Jadi anggota kelompok akan belajar tentang dirinya dalam hubungannya dengan anggota lain atau orang lain, selain itu dalam konseling kelompok anggota kelompok dapat pula belajar memecahkan masalah berdasarkan masukan dari anggota lain (Smith, 2011).

Hasil yang sama juga diperoleh dari penelitian Yuliana (2015) yang menyatakan bahwa dengan konseling kelompok mampu meningkatkan kualitas hidup individu dengan membantu menemukan tujuan hidup dan makna dalam hidup sehingga dapat mengurangi kecemasan. Abood dan Melhim (2015) juga menjelaskan bahwa dengan konseling kelompok akan membantu individu menghadapi ketakutan yang dimilikinya.

Pendekatan realita dalam konseling kelompok menjadi salah satu alternatif bagi klien pemasyarakatan untuk menurunkan kecemasan mereka. Seseorang yang cemas akan menunjukkan rasa khawatir tentang sesuatu, perasaan terganggu, ketakutan terhadap sesuatu yang terjadi di masa depan, keyakinan bahwa sesuatu yang menakutkan akan segera terjadi, ketakutan akan ketidakmampuan untuk mengatasi masalah, pikiran terasa bercampur aduk atau kebingungan, atau sulit berkonsentrasi Nevid, Rathus, \& Greene (2003). Pemberian konseling kelompok dengan pendekatan realita akan membantu klien pemasyarakatan untuk menghadapi realita kehidupan mereka. Konseling kelompok realita mengajarkan anggota kelompok untuk menerima tanggung jawab terhadap perubahan perilaku. Konseling kelompok realita mengajarkan klien untuk bertanggung jawab terhadap seluruh keputusan yang mereka perbuat, apakah mereka memutuskan untuk berubah atau tidak (Jusoh dan Hussain, 2015).

Pelaksanaan intervensi pada penelitian ini merujuk pada prosedur pelaksanaan terapi realita yang dikemukakan Glasser (dalam Corey, 2009) yaitu wants, direction and doing, evaluation, dan planning. Pada pertemuan awal subjek diajak untuk menentukan apa yang menjadi keinginan sebagai bentuk kebutuhan dasar mereka. Kemudian mereka diminta untuk menentukan rencana yang akan diambil. Pada tahap selanjutnya mereka diminta untuk mengevaluasi rencana mereka sehingga akhirnya mereka bisa benar-benar merencanakan tahap-tahap yang akan dilakukan untuk mewujudkan rencana yang telah mereka susun dan anggota kelompok dapat fokus pada pengembangan diri serta menghadapi kecemasan-kecemasannya. Hal tersebut sejalan dengan penelitian yang dilakukan oleh Farmani dkk (2015) yang menyatakan bahwa terapi kelompok realita dapat membantu anggota kelompok mengekspresikan dirinya dan menanyakan berbagai 
hal, sehingga bisa mengajarkan mereka untuk menghadapi perasaan negatif dan mengontrol apa yang mereka rasakan.

Konseling kelompok realita yang diberikan pada kelompok eksperimen terbukti efektif untuk menurunkan kecemasan pada klien pemasyarakatan di Balai Pemasyarakatan kelas II Mataram. Hal tersebut tampak dari perbedaan yang signifikan pada hasil skor posttest pada kelompok eksperimen dan kelompok kontrol. Kelompok eksperimen yang diberikan intervensi berupa konseling kelompok realita memiliki tingkat kecemasan yang berbeda dengan kelompok kontrol yang tidak diberikan intervensi berupa konseling kelompok realita. Pemberian perlakuan berupa konseling kelompok realita terbukti menurunkan tingkat kecemasan pada kelompok eksperimen. Hasil pengukuran efektivitas intervensi konseling kelompok realita juga menunjukkan efektivitas yang besar pada menurunnya tingkat kecemasan pada klien pemasyarakatan yang diberikan konseling kelompok realita.

Keaktifan subjek pada kelompok eksperimen dalam mengikuti kegiatan konseling kelompok realita dinilai merupakan faktor penting dalam menurunnya tingkat kecemasan. Subjek penelitian tampak belum mau terbuka di tahap-tahap awal konseling kelompok, akan tetapi seiring berjalannya proses konseling kelompok realita mereka dapat mengikuti tahap demi tahap kegiatan sesuai dengan rencana. Tiap-tiap anggota kelompok sudah memiliki rencana yang baik bagi kehidupan mereka. Anggota kelompok lain, meskipun tidak memberikan masukan konstruktif secara langsung, juga memberikan dukungan yang positif kepada anggota kelompok lainnya. Proses konseling kelompok realita yang berjalan dengan baik tersebut dinilai menjadi faktor yang menurunkan tingkat kecemasan pada klien pemasyarakatan di Balai Pemasyarakatan Kelas II Mataram.

Penurunan kecemasan yang terjadi ditunjukkan dengan menurunnya nilai rata-rata skor kecemasan setelah pemberian intervensi. Secara umum semua subjek yang berada pada kelompok eksperimen mengalami penurunan tingkat kecemasan setelah pemberian konseling kelompok realita. Hal tersebut membuktikan bahwa konseling kelompok ralita efektif untuk menurunkan kecemasan pada klien pemsayarakatan di Balai Pemasyarakatan Kelas II Mataram.

\section{SIMPULAN DAN IMPLIKASI}

Simpulan dari penelitian ini adalah konseling kelompok realita efektif untuk menurunkan kecemasan pada klien pemasyarakatan di Balai Pemasyarakatan Kelas II Mataram. Hal ini dibuktikan dengan hasil uji beda juga menunjukkan perbedaan yang signifikan antara kelompok eksperimen dengan kelompok kontrol setelah pemberian intervensi berupa konseling kelompok realita, dimana tingkat kecemasan pada kelompok eksperimen diketahui mengalami penurunan. Hasil perhitungan effect size juga menunjukkan hasil tingkat efektivitas besar dari pemberian konseling kelompok realita terhadap penurunan tingkat kecemasan pada klien pemasyarakatan di Balai Pemasyarakatan Kelas II Mataram.

Peneliti selanjutnya diharapkan melakukan kontrol yang ketat terutama pada pemberian posttest pada kelompok kontrol. Peneliti selanjutnya dapat melakukan pengembangan 
dari penelitian ini dengan menggunakan intervensi yang sama namun pada subjek yang berbeda. Hal ini diharapkan mampu memberikan bukti bagi efektivitas konseling kelompok realita untuk menurunkan kecemasan.

Penelitian selanjutnya dapat mempertimbangkan intervensi berupa Konseling Kelompok Realita yang pada penelitian ini menjadi variabel $X$ untuk digunakan menjadi sebuah konsep yang bervariasi dan membentuk variebel $\mathrm{X}$.

Subjek sebaiknya bisa selalu terbuka kepada orang lain baik itu keluarga, petugas pemasyarakatan, maupun klien pemasyarakatan lainnya agar selalu terhindar dari kecemasan. Subjek dapan melaksanakan tahapan-tahapan konseling kelompok realita yaitu wants, direction and doing, evaluation, dan planning apabila rasa cemas datang di kemudian hari. Subjek juga dapat membentuk kelompok-kelompok kecil untuk berbagi kepada klien pemasyarakatan lainnya agar bisa saling memberikan solusi mengenai permasalahan yang dihadapi.

Kegiatan konseling kelompok realita bisa menjadi salah satu pilihan program pembimbingan kepribadian yang dapat dilaksanakan di Balai Pemasyarakatan Kelas II Mataram mengingat tugas dan fungsi utama dari organisasi yaitu pembimbingan klien. Pihak Balai Pemasyarakatan Kelas II Mataram bisa membentuk support group untuk memfasilitasi permasalahan yang dihadapi oleh klien pemasyarakatan.

\section{REFERENSI}

Abood, M. H., \& Abu-Melhim, A. H. (2015). Examining the Effectiveness of Group Counseling in Reducing Anxiety for Jordanian EFL Learners. Journal of Language Teaching and Research, 6 No. 4, 749-757.

Amelia, K. R. (2010). Hubungan Dukungan Sosial dengan Kecemasan Menghadapi Masa Pembebasan pada Narapidana di Lembaga Pemasyarakatan Kelas II A Pekanbaru. Riau: Fakultas Psikologi Universitas Islam Negeri Sultan Syarif Kasim.

Astuti, B. (2012). Modul Konseling Kelompok. Yogyakarta: FIP UNY.

Brennan, L. (2013). Effectiveness of Group Cognitive Behavioural Intervention in Reducing Anxiety in Irish Prisoners: Quantitative and Qualitative Analysis. Small Scale Research Project.

Chikadzi, V. (2017). Challenges Facing Ex-Offenders When Reintegrating Into Mainstream Society in Gauteng, South Africa. Social Work/Maatskaplike Werk, Vol. 53 No. 2 Issue 8.

Corey, G. (2009). Teori dan Praktek Konseling dan Psikoterapi. Bandung: Rafika Aditama.

Corey, M., \& Corey, G. (2006). Groups: Process and Practice. Belmont, CA: Thomson Brooks/Cole. 
Dadashazar, N. (2017). Offender Recidivism: A Quantitative Study of Motivational Risk Factors and Counseling. Walden University ScholarWorks.

Dixon, T. (2012). Understanding Anxiety Problems. Help-for Publishing.

Farmani, F., Taghavi, H., Fatemi, A., \& Safavi, S. (2015). The Efficacy of Group Reality Therapy on Reducing Stress, Anxiety and Depression in Patients wiith Multiple Sclerosis (MS). Behavioral Research Center of SBMU.

Field, A. (2009). Discovering Statistic Using SPSS (3rd ed). London: Sage Publication, Inc.

Gharavi, M. M., Kashani, H., Lotfi, M., \& Borhani, M. (2015). Comparison of Depression, Anxiety, General Mental Health and Self-Esteem Among Prisoners in Consultancy and Ordinary Wings. Journal of Fundamentals of Mental Health, $17(1), 7-52$.

Glasser, W. (2004). New Vision for Counseling. The Family Journal: Counseling and Therapy for Couples and Families, 12 No.4, 339-341.

Gorgulu, T., \& Erden, G. (2015). Problems, Needs, and Psychological State of ExConvicts: A Qualitative Study in a Turkish Sample. Journal of Education Research and Behaviornal Sciences, 4 (3), 110-124.

Hanun, I. B. (2013). Studi Tentang Penyesuaian Diri Mantan Narapidana di Kecematan Banjarnegara Kabupaten Banjarnegara. Program Studi Bimbingan dan Konseling, Jurusan Psikologi Pendidiakn dan Bimbingan, Fakultas Ilmu Pendidikan Universitas Negeri Yogyakarta.

Jusoh, A. J., \& Hussain, S. P. (2015). Choice Theory and Reality Therapy (CTRT) Group Counseling Module. Asian Journal of Humanities and Social Studies, 3.

Moran, D. (2015). Prisoner Reintegration and The Stigma of Prison Time Inscribed On The Body. Sage Publication.

Nevid, S., Rathus, A., \& Greene, B. (2003). Psikologi Abnormal Edisi Kelima Jilid 1. Jakarta: Erlangga.

Patandean, S. T. (2017). Efektivitas Cognitive Behaviour Therapy untuk Menurunkan Kecemasan Narapidana Menjelang Bebas di Lapas Kelas II A Pamekasan. Tesis Fakultas Psikologi Universitas Airlangga.

Schnittker, J., Massoglia, M., \& Uggen, C. (2012). Out and Down; Incercaration and Psychiatric Disorders. Journal of Health and Social Behaviour, 53 (4), 448-464.

Seligman, E., Walker, E., \& Rosenhan, D. (2001). Abnormal Psychology Fourth Edition. New York, London: W.W Norton \& Company.

Shinkfield, A., \& Graffam, J. (2010). The Relationship Between Emotional State and Success in Community Reintegration for Ex-Prisoners. International Journal of Offender Therapy and Comparative Criminology, 54 No. 3, 346-360. 
Smith, E. J. (2011). Theories of Counseling and Psychotherapy: An Integrative Approach. Thousand Oaks: Sage Publications, Inc.

Western, B., Braga, A., Davis, J., \& Sirois, C. (2014). Stress and Hardship After Prison. Cambridge: Department of Sociology.

Yuliana. (2015). Mengatasi Kecemasan terhadap Kematian pada Pasien Sakit Parah Melalui Konseling Kelompok. Psychology Forum UMM. 